\title{
The Middle East and North Africa (MENA) Oil Exporters After the Global Crisis
}

\author{
Naci Y1lmaz \\ Türkiye İş Bankası, İstanbul, Turkey \\ Bora Selçuk \\ Kadir Has Üniversitesi, İstanbul, Turkey
}

\begin{abstract}
Our research topic is about the economic situation in the Middle East and North Africa (MENA) oil exporters after the global crisis in 2008. The authors tried to find the answers to the questions such as "How bad or good is the situation there?” and “what is the expectation about the future of the region?” Like other countries around the world, the MENA oil exporters, comprised of Algeria, Bahrain, Iran, Iraq, Kuwait, Libya, Oman, Qatar, Saudi Arabia, Sudan, United Arab Emirates, Yemen were adversely affected by the global crisis. The MENA oil exporters are recently recovering from their recession in 2009 when the global crisis was felt intensively there. GDP in the region has grown by 3.5 percent in 2010 after a low growth of 0.7 percent in 2009. The average real GDP growth excluding Libya is projected to reach 4.9 percent in 2011. Two developments mark the outlook: the unrest in the region and the surge in global fuel and food prices. For most oil exporters, the expected increase in oil prices and production volumes will lead to higher growth in 2011 and stronger fiscal and external balances, notwithstanding recent increases in government spending. The oil exporters' combined external current account surplus is estimated to increase. The effects of the political events in Tunisia and Egypt have spread in varying degrees to the MENA oil exporters in the region, and many of these countries are responding with public spending and job-creation measures to alleviate social tensions. The social unrest also highlights the need to pursue fundamental economic reforms - social policy, fiscal management, governance, business environment, labor markets, and financial sector access to facilitate more inclusive economic growth. While the MENA countries are generally divided into two sub-regions such as "oil exporters" and "oil importers" in the economic literature, the authors will deal with only the MENA oil exporters in this work. The negative effects of the global crisis in these countries on growth, inflation, current account balance, budget balance, and finally financial sector will be reviewed in this work and the expectations and the developments which occurred after the crisis in these countries will be dealt with especially in the context of the IMF reports.
\end{abstract}

Keywords: global crisis, the Middle East and North Africa (MENA), MENA oil exporters

Naci Yılmaz, Ph.D., Branch Manager, Türkiye İş Bankası.

Bora Selçuk, Ph.D., The Head of Banking and Insurance Department, School of Social Sciences, Kadir Has University.

Correspondance concerning this article should be addressed to Naci Yılmaz, Türkiye İş Bankası, Çamlıca, İstanbul, Turkey.

E-mail: nakiyilmaz@yahoo.com. 


\section{Introduction}

The term "MENA", for "Middle East and North Africa", is an acronym often used in academic, military planning, and business writing. The term covers an extensive region, extending from Morocco to Iran, including the majority of both the Middle Eastern and Maghreb countries. The region consists of Mauritania, Morocco, Algeria, Tunisia, Libya, Egypt, Sudan, Lebanon, Jordan, Syria, Iraq, Saudi Arabia, Djibouti, Yemen, Oman, United Arab Emirates, Qatar, Bahrain, Kuwait, Iran, and Afghanistan. The term is roughly synonymous with the term "the Greater Middle East" (which is also sometimes taken to include Pakistan, Afghanistan, or both). The population of the MENA region at its least extent is about 381 million people, about $6 \%$ of the total world population. At its greatest extent, its population is roughly 523 million (Wikipedia, 2011).

The 2008-2009 financial crisis, which originated in the United States and rapidly spread to the rest of world, resulting in the most severe and intense Great Recession since World War II, has posed new challenges for international policy coordination and the management of national economies. Questions are being raised about globalization, which has been a powerful engine of economic growth over the past three decades but exposes countries to more volatility and increases risk (Nabli, 2010). While having a global impact, the current financial and economic crisis is clearly affecting certain regions more severely than others. One region which may be amongst the worst affected is the MENA region. The estimated spillover of the global crisis to emerging market economies in the MENA indicates that nearly two-thirds of the increased financial stress in MENA emerging market countries after the Lehman shock is attributable to direct or indirect spillovers of financial stress in advanced economies (Moriyama, 2010).

For some this might be surprising, given perceptions that either the region is wealthy due to its oil riches, or countries have plenty of foreign exchange reserves to tide them over, or the region's banking system is not as exposed to adverse changes in the global financial system. But the region may be one of the worst affected regions worldwide. It is a diverse region containing both very rich and very poor countries, with a very high dependency on international markets (The World Bank, 2005). The region is also facing significant demographic pressures and lacks effective regional integration and well-functioning social safety nets. In the region about 40-50 percent of people live on less than two dollars a day. The unemployment rate in the region is around 12 percent that is amongst the highest rate in the world. A huge concern is that amongst the young unemployment exceeds 40 percent. Compared with other developing regions, the region is more dependent on remittances (almost 7 percent of GDP), more dependent on international tourism (14 percent of GDP) and more dependent on fuel exports (56 percent of GDP). The region is more dependent on food imports. Countries in the region generally import more than 50 percent of their agricultural products; the agricultural trade balance recorded a deficit of US\$ 25 billion and a food deficit of US\$18 billion in 2006 (Drine, 2009, p. 3).

MENA region is rich in natural and human resources, labor, GDP, and population. Its countries vary, in some cases considerably, in economic size, population, public/private sector balances, and financial and natural resources (Guetat \& Serranito, 2001). The region can be divided into two main groups of countries (see Figure 1). The first is the oil producing and exporting countries. It contains Algeria, Libya, Sudan, Saudi Arabia, Yemen, Oman, UAE, Qatar, Bahrain, Kuwait, Iraq, and Iran. This group (excluding Sudan, Yemen, and Iraq) has the highest level of GDP per capita and the lowest unemployment rate; with a high level of exchange 
reserves, these countries are in a better position to face the crisis. For these countries oil contributes 36 percent of total value added, 85 percent of export revenues and 71 percent of government fiscal receipts, indicating that these economies are still overwhelmingly dependent on petroleum. While the value added of the petroleum industry represents 36 percent of the region's aggregate GDP, its contribution to employment, including all petroleum-related activities, is less than 5 percent. The second group is called as “oil importers". They are more diversified but relatively vulnerable, and have poor economies. This group includes Mauritania, Morocco, Tunisia, Egypt, Jordan, Lebanon, Syria, Djibouti, and Afganistan.These countries are integrated into the global economy and depend on imports both for consumption and investment. Export, foreign direct investment, remittances and tourism play a key role in economic growth and job creation in these nations. This group of countries, already facing with high unemployment and external deficit, do not have sufficient domestic demands to mitigate the fall in the external demand, because of low GDP per capita.

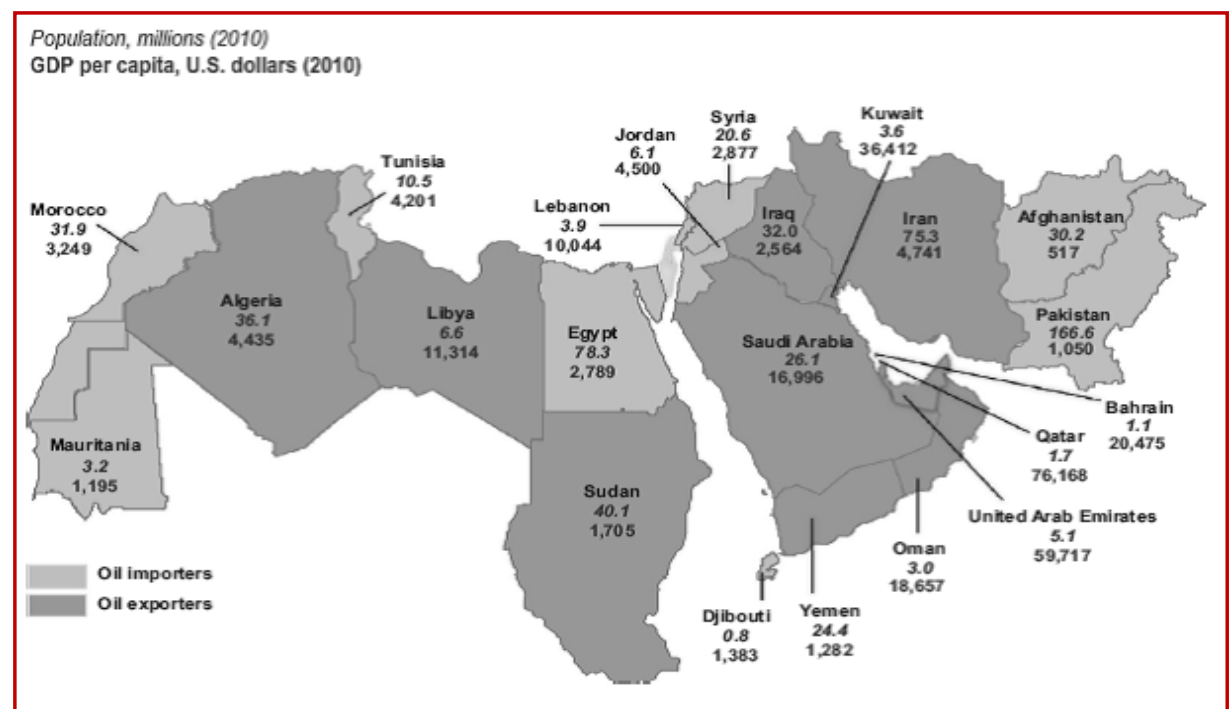

Figure 1. Population and GDP in MENA countries in 2010. Source: IMF, 2011a.

The spark ignited by the death of Mohammed Bouazizi has irretrievably changed the future course of the countries in MENA (IMF, 2011b). The Middle East and North Africa is going through a period of unseen change. Even though it is clear that the popular uprisings are born from a desire for greater political, social, and economic freedom, their timing come as a surprise to everyone, including the IMF. The roots of the surprising are political, but economic causes are inextricably entwined. Until the late 2010, the region was on track for recovery from the global crisis. Growth accelerated to 3.9 percent in 2010 from 2.1 percent in 2009, mainly driven by the region's oil exporters. Nevertheless, the slow growth equilibrium of the past years did not generate enough jobs for the growing labor force. The unfolding events make it clear that reforms, an even rapid economic growth as seen periodically in Tunisia and Egypt, cannot be sustained unless they create jobs for the rapidly growing labor force and are accompanied by social policies for the most vulnerable. For growth to be sustainable, it must be inclusive and broadly shared, and not just captured by a privileged few.

Two developments mark the outlook: the unrest in the region and the surge in global fuel and food prices. As a result, the near-term economic outlook is unusually subject to large uncertainties stemming from the fluid 
political and security situation in a number of countries. For most oil exporters, the expected increase in oil prices from US\$79 per barrel to US\$107 per barrel and production volumes will lead to a higher growth in 2011 and stronger fiscal and external balances, notwithstanding recent increases in government spending. The average real GDP growth (excluding Libya) is projected to reach 4.9 percent in 2011 compared with 3.5 percent in 2010, while non-oil growth is projected to stay at 3.5 percent in 2011. For the GCC, growth is projected to reach 7.8 percent in 2011 as oil production expands to stabilize global oil supply in the face of supply disruption elsewhere. GCC non-oil growth is set to accelerate by more than 1 percentage point to 5.3 percent in 2011. The oil exporters' combined external current account surplus is estimated to increase from US\$172 billion to US\$378 billion (excluding Libya), and for the GCC from US\$136 billion to US\$304 billion (see Table 1).

Table 1

Current Account, Fiscal Balances in MENA

\begin{tabular}{|c|c|c|c|c|c|}
\hline & Average & & & & Proj. \\
\hline & $2000-07$ & 2008 & 2009 & 2010 & 2011 \\
\hline \multicolumn{6}{|l|}{ MENAP' } \\
\hline Real GDP (annual growth) & 5.4 & 4.7 & 2.1 & 3.9 & 3.9 \\
\hline Current Account Balance & 9.5 & 13.3 & 1.7 & 5.9 & 11.7 \\
\hline Overall Fiscal Balance & 3.2 & 6.7 & -3.6 & -0.2 & 2.4 \\
\hline Inflation, p.a. (annual growth) & 6.2 & 14.3 & 7.6 & 7.5 & 10.8 \\
\hline \multicolumn{6}{|l|}{ MENAP Oil Exporters ${ }^{*}$} \\
\hline Real GDP (annual growth) & 5.6 & 4.7 & 0.7 & 3.5 & 4.9 \\
\hline Current Account Balance & 13.4 & 18.8 & 4.2 & 9.2 & 16.9 \\
\hline Overall Fiscal Balance & 7.3 & 12.9 & -2.7 & 3.0 & 7.5 \\
\hline Inflation, p.a. (annual growth) & 6.9 & 14.8 & 5.8 & 6.8 & 10.9 \\
\hline \multicolumn{6}{|c|}{ Of Which: Gulf Cooperation Council } \\
\hline Real GDP (annual growth) & 5.6 & 7.2 & 0.2 & 5.0 & 7.8 \\
\hline Current Account Balance & 15.7 & 22.5 & 7.6 & 12.5 & 21.7 \\
\hline Overall Fiscal Balance & 11.9 & 24.7 & -0.8 & 7.2 & 12.6 \\
\hline Inflation, p.a. (annual growth) & 2.2 & 11.0 & 3.0 & 3.2 & 5.3 \\
\hline \multicolumn{6}{|l|}{ MENAP Oil Importers } \\
\hline Real GDP (annual growth) & 4.8 & 4.8 & 4.7 & 4.7 & 2.3 \\
\hline Current Account Balance & -0.8 & -4.6 & -4.6 & -3.3 & -4.1 \\
\hline Overall Fiscal Balance & -5.1 & -5.4 & -5.2 & -6.0 & -6.8 \\
\hline Inflation, p.a. (annual growth) & 4.7 & 13.3 & 11.1 & 8.8 & 10.7 \\
\hline \multicolumn{6}{|l|}{ Memorandum } \\
\hline \multicolumn{6}{|l|}{ MENA $^{*}$} \\
\hline Real GDP (annual growth) & 5.4 & 5.1 & 1.8 & 3.8 & 4.1 \\
\hline Current Account Balance & 10.4 & 14.9 & 2.4 & 6.5 & 12.7 \\
\hline Overall Fiscal Balance & 4.1 & 8.6 & -3.4 & 0.6 & 3.3 \\
\hline Inflation, p.a. (annual growth) & 6.2 & 14.5 & 6.1 & 7.0 & 10.2 \\
\hline \multicolumn{6}{|l|}{ MENA Oil Importers } \\
\hline Real GDP (annual growth) & 4.7 & 6.4 & 4.8 & 4.5 & 1.9 \\
\hline Current Account Balance & -1.0 & -3.1 & -4.2 & -3.8 & -5.2 \\
\hline Overall Fiscal Balance & -6.6 & -4.5 & -5.4 & -6.2 & -7.9 \\
\hline Inflation, p.a. (annual growth) & 4.2 & 13.5 & 7.0 & 7.6 & 8.3 \\
\hline
\end{tabular}

Note. Source: IMF, 2011a. 
Governments across the region are responding to political developments and higher commodity prices with expansions of fuel and food subsidies, civil service wage and pension increases, additional cash transfers, tax reductions, and other spending increases. The size of the national fiscal packages in 2011 ranges from less than 0.5 percent of GDP in some MENA oil importers to about 22 percent of GDP in Saudi Arabia (with the spending spread over several years). While some countries can easily afford this extra spending, others will find it straining public finances and debt levels: Support from the international community would help bridge financing needs and contain the buildup of debt.

Inflation has been accelerated across the region, mainly driven by higher international commodity prices. However, there are indications that food and fuel inflation are spilling over into core inflation. More generally, with food and fuel accounting for about half of MENA countries' consumer price indices, and commodity price shocks are likely to be rather persistent, regional central banks will need to pay greater attention to headline inflation when setting policy rates and the overall stance of monetary policy. Upward pressure on policy rates will also come from a rising global interest rate environment and increase sovereign risk premiums.

Beyond the immediate challenges, the recent uprisings provide a great opportunity to lay the foundation for a socially inclusive growth agenda for the Middle East. Each country must find its own homegrown path for the change that is broadly owned, but all will need to respond to some common goals to realize the region's longer-term potential: a stable macroeconomic environment to provide confidence and attract investment; enough private-sector jobs to absorb the currently unemployed and a fast-growing labor force; access to economic opportunity for citizens to realize their potential; social protection for the vulnerable; and strong and transparent institutions that ensure accountability and good governance. The aim is not just the sustained high growth, but also the growth that is more inclusive and results in broadly shared development gains.

There are many uncertainties about the MENA region's future. Nonetheless, the region has much strength on which to build: a dynamic and young population, vast natural resources, a large regional market, an advantageous geographic position, and access to key markets. While the months ahead will be challenging and inevitably marked by setbacks, there is momentum for the change to build upon.

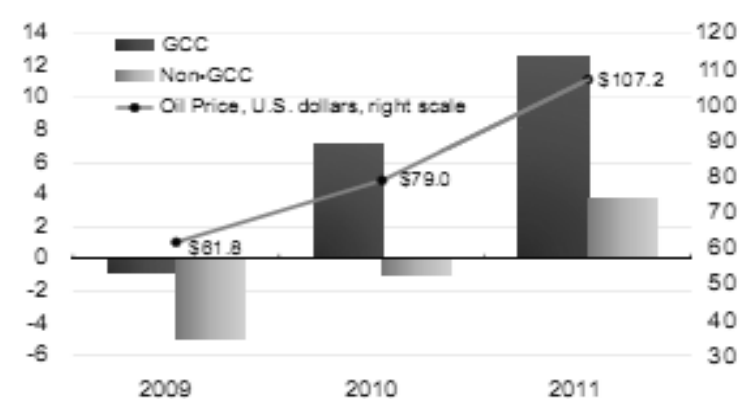

Figure 2. Fiscal balance in MENA oil exporters (percent of GDP). Source: IMF, 2011a.

\section{Opportunity of MENA Oil Exporters for Reforms}

Sharp increases in oil prices, particularly after the beginning of the recent events in the region, have benefited the MENA oil exporters' fiscal and current account surpluses (see Figure 2). Part of the increased oil revenues have been used to respond to social tensions. In managing the short-term uncertainties, oil exporters should not lose sight of their longer-term challenges: achieving strong and sustainable inclusive growth to 
provide employment for the rapidly growing labor force, especially for the youth; better fiscal management; and further development of the financial system.

\section{Financial Growth but Rising Uncertainty}

The effects of the political events in Tunisia and Egypt have spread in varying degrees to the oil exporters in the region, and many of these countries are responding with public spending and job-creation measures to alleviate social tensions. The social unrest also highlights the need to pursue fundamental economic reforms-social policy, fiscal management, governance, business environment, labor markets, and financial sector access to facilitate more inclusive economic growth. The unrest has increased the assessment of risk in the region, but the consequential hike in oil prices has brought in rising financial benefits. The average spot oil prices, which had steadily increased by 25 percent to US\$95 per barrel between August 2010 and January 2011shot up amid greater volatility to over US\$110 per barrel during March. Prices were increased further in early April, as social and political unrest had been intensified in Libya, which also placed increased emphasis on the role of other oil producers in stabilizing oil supplies (see Figure 3).

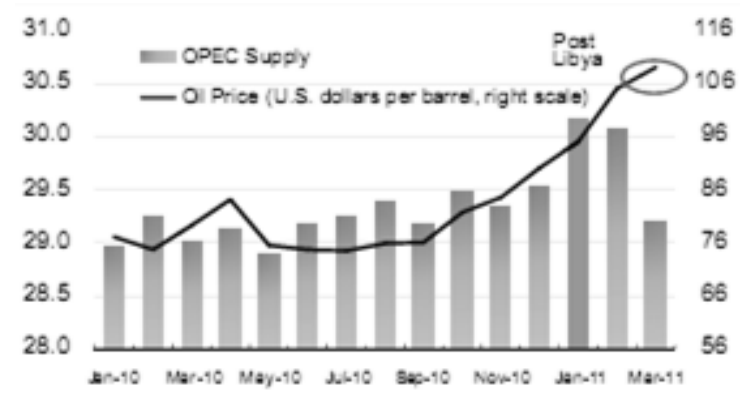

Figure 3. Crude oil prices (millions of barrels per day). Source: IMF, 2011a.

Growth is likely to be uneven in 2011, but the GCC as a group is racing ahead. The average economic growth is expected to increase to 4.9 percent in 2011 for the MENA oil exporters (excluding Libya). Bahrain, Iran, Libya, Sudan, and Yemen are likely to be negatively affected, but the rest are expected to grow well above the trend. In particular, the GCC is expected to show particularly strong growth of 7.8 percent in 2011, driven mainly by the oil sector as countries' expand production, but also supported by high levels of public spending (Global Research-MENA, 2011). The strongest performer is expected to be Qatar at 20 percent, underpinned by the continuous gas expansion and large public investments, followed by Saudi Arabia at 7.5 percent, where much of the increase is from the enhanced oil production. Among the non-GCC countries, growth is expected to decline sharply in Libya, where the conflict has severely disrupted the hydrocarbon sector (account for over 70 percent of GDP and 90 percent or more of Libyan exports and government revenue) (see Table 2).

Non-oil growth is expected to remain robust across countries (except in Iran), mainly as a result of additional fiscal spending (Figure 4). Growth in Iran is likely to remain below the trend in 2011 as the economy responds to the implementation of energy subsidy reform that began in December 2010 and which is expected to have positive long-term benefits. In Sudan, the six-month transition period prior to the July 2011 independence of South Sudan could result in lower growth rates in 2011. The performance of GCC countries will remain strong in 2011, with the exception of Bahrain, where uncertainties prevail. Robust non-oil growth in the region partly 
reflects implementation of plans to promote economic diversification by amending some measures such as adopting foreign direct investment (FDI) laws, initiating public-private partnerships, and encouraging joint ventures are aiming to broaden the tax base and generate employment; joblessness remains high, particularly among the youth in many of these countries.

Table 2

GDP, CPI, Current Account Balance and Other Indicators in MENA Countries

\begin{tabular}{|c|c|c|c|c|c|c|c|}
\hline & $\begin{array}{l}\text { Average } \\
2000-05\end{array}$ & 2006 & 2007 & 2008 & 2009 & 2010 & $\begin{array}{l}\text { Proj. } \\
2011\end{array}$ \\
\hline Real GDP Growth & 5.6 & 5.7 & 6.2 & 4.7 & 0.7 & 3.5 & 4.9 \\
\hline \multicolumn{8}{|l|}{ (Annual change; percent) } \\
\hline Algeria & 4.5 & 2.0 & 3.0 & 2.4 & 2.4 & 3.3 & 3.6 \\
\hline Bahrain & 6.0 & 6.7 & 8.4 & 6.3 & 3.1 & 4.1 & 3.1 \\
\hline Iran, I.R. of & 5.5 & 5.8 & 7.8 & 1.0 & 0.1 & 1.0 & 0.0 \\
\hline Iraq & $\ldots$ & 6.2 & 1.5 & 9.5 & 4.2 & 0.8 & 9.6 \\
\hline Kuwait & 7.1 & 5.3 & 4.5 & 5.0 & -5.2 & 2.0 & 5.3 \\
\hline Libya & 4.3 & 6.7 & 7.5 & 2.3 & -2.3 & 4.2 & $\ldots$ \\
\hline Oman & 3.3 & 5.5 & 6.7 & 12.9 & 1.1 & 4.2 & 4.4 \\
\hline Qatar & 8.7 & 18.6 & 26.8 & 25.4 & 8.6 & 16.3 & 20.0 \\
\hline Saudi Arabia & 4.0 & 3.2 & 2.0 & 4.2 & 0.6 & 3.7 & 7.5 \\
\hline Sudan & 6.4 & 11.3 & 10.2 & 6.8 & 6.0 & 5.1 & 4.7 \\
\hline United Arab Emirates & 8.1 & 8.8 & 6.5 & 5.3 & -3.2 & 3.2 & 3.3 \\
\hline Yemen & 4.5 & 3.2 & 3.3 & 3.6 & 3.9 & 8.0 & 3.4 \\
\hline Consumer Price Inflation & 5.9 & 8.8 & 11.2 & 14.8 & 5.8 & 6.8 & 10.9 \\
\hline \multicolumn{8}{|l|}{ (Year average; percent) } \\
\hline Algeria & 2.3 & 2.3 & 3.6 & 4.9 & 5.7 & 4.3 & 5.0 \\
\hline Bahrain & 0.7 & 2.0 & 3.3 & 3.5 & 2.8 & 2.0 & 3.0 \\
\hline Iran, I.R. of & 13.5 & 11.9 & 18.4 & 25.4 & 10.8 & 12.5 & 22.5 \\
\hline Iraq & 19.8 & 53.2 & 30.8 & 2.7 & -2.8 & 5.1 & 5.0 \\
\hline Kuwait & 1.7 & 3.1 & 5.5 & 10.6 & 4.0 & 4.1 & 6.1 \\
\hline Libya & -3.3 & 1.4 & 6.2 & 10.4 & 2.8 & 2.4 & $\ldots$ \\
\hline Oman & 0.1 & 3.4 & 5.9 & 12.6 & 3.5 & 3.3 & 3.5 \\
\hline Qatar & 3.5 & 11.8 & 13.8 & 15.0 & -4.9 & -2.4 & 4.2 \\
\hline Saudi Arabia & -0.1 & 2.3 & 4.1 & 9.9 & 5.1 & 5.4 & 6.0 \\
\hline Sudan & 7.6 & 7.2 & 8.0 & 14.3 & 11.3 & 13.0 & 9.0 \\
\hline United Arab Emirates & 3.6 & 9.3 & 11.1 & 12.3 & 1.6 & 0.9 & 4.5 \\
\hline Yemen & 11.6 & 10.8 & 7.9 & 19.0 & 3.7 & 12.1 & 13.0 \\
\hline General Government Fiscal Balance & 5.8 & 13.2 & 10.3 & 12.9 & -2.7 & 3.0 & 7.5 \\
\hline \multicolumn{8}{|l|}{ (Percent of GDP) } \\
\hline Algeria & 6.6 & 13.5 & 4.4 & 7.7 & -6.8 & -2.7 & 5.0 \\
\hline Bahrain $^{2}$ & 1.4 & 2.7 & 1.9 & 4.9 & -6.6 & -7.8 & 1.6 \\
\hline Iran, I.R. of & 2.0 & 0.0 & 2.4 & -0.2 & -1.9 & 0.6 & 4.0 \\
\hline Iraq & $\ldots$ & 15.5 & 12.4 & -1.2 & -21.8 & -10.8 & -4.4 \\
\hline Kuwait $^{2}$ & 27.2 & 35.4 & 39.8 & 19.8 & 23.5 & 17.4 & 22.3 \\
\hline Libya & 12.6 & 33.1 & 28.6 & 30.3 & 7.0 & 9.2 & $\ldots$ \\
\hline Oman ${ }^{2}$ & 8.4 & 13.8 & 11.1 & 13.8 & -1.2 & 6.2 & 14.2 \\
\hline Qatar & 8.8 & 8.6 & 10.8 & 10.3 & 15.2 & 12.8 & 13.8 \\
\hline Saudi Arabia & 7.7 & 24.6 & 15.8 & 34.4 & -4.7 & 7.7 & 12.8 \\
\hline Sudan & -0.6 & -4.3 & -5.4 & -1.4 & -4.6 & -1.9 & -0.2 \\
\hline United Arab Emirates ${ }^{3}$ & 4.5 & 18.1 & 15.4 & 16.5 & -12.6 & -1.3 & 6.5 \\
\hline Yemen & 0.0 & 1.2 & -7.2 & -4.5 & -10.2 & -4.0 & -6.4 \\
\hline Current Account Balance & 11.2 & 21.9 & 17.9 & 18.8 & 4.2 & 9.2 & 16.9 \\
\hline \multicolumn{8}{|l|}{ (Percent of GDP) } \\
\hline Algeria & 14.0 & 24.7 & 22.8 & 20.2 & 0.3 & 9.4 & 17.8 \\
\hline Bahrain & 5.0 & 13.8 & 15.7 & 10.2 & 2.9 & 4.6 & 13.0 \\
\hline Iran, I.R. of & 5.2 & 9.2 & 11.9 & 7.3 & 4.2 & 6.0 & 11.7 \\
\hline Iraq & $\ldots$ & 19.0 & 12.5 & 12.8 & -26.6 & -6.2 & -3.2 \\
\hline Kuwait & 26.2 & 44.6 & 36.8 & 40.5 & 26.1 & 31.8 & 39.4 \\
\hline Libya & 18.9 & 49.7 & 41.7 & 41.7 & 15.6 & 16.0 & $\ldots$ \\
\hline Oman & 9.4 & 15.4 & 5.9 & 8.3 & -0.6 & 11.6 & 14.9 \\
\hline Qatar & 25.2 & 25.3 & 25.0 & 29.2 & 10.2 & 18.7 & 36.1 \\
\hline Saudi Arabia & 13.6 & 27.8 & 24.3 & 27.8 & 6.1 & 8.7 & 19.8 \\
\hline Sudan & -9.5 & -15.2 & -12.5 & -9.0 & -12.4 & -8.5 & -5.5 \\
\hline United Arab Emirates & 7.7 & 15.4 & 6.0 & 7.4 & 3.0 & 7.7 & 10.4 \\
\hline Yemen & 5.3 & 1.1 & -7.0 & -4.6 & -10.2 & -4.4 & -4.0 \\
\hline
\end{tabular}

Note. Source: IMF, 2011a. 
Financial markets have taken a hit. Equity markets across MENA oil exporters have fallen since January 11, and some markets (Bahrain, Dubai) are now around the troughs in the aftermath of the 2008 global crisis. Sovereign credit default swap spreads have been widened in all GCC countries after the current crisis, but they are narrower than the post-global crisis levels. Rating agencies have downgraded Bahrain and Libya since the beginning of the unrest.

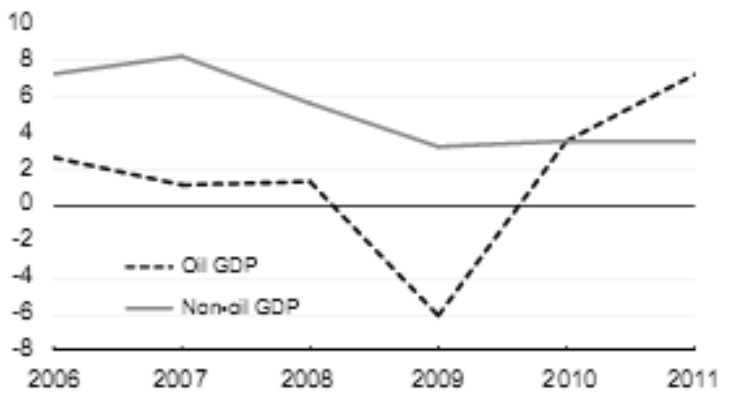

Figure 4. Growth in MENA oil exporters (GDP growth; percent). Source: IMF, 2011a.

Fiscal and external balances are improving amid oil price uncertainty. Strong growth in oil revenue will generate substantial fiscal and current account surpluses in 2011. The current account surplus of the oil exporters (excluding Libya) in 2011 is projected at about US\$378 billion, with the GCC countries accounting for about US\$304 billion. Nevertheless, considerable uncertainty surrounds these projections. For the oil exporters as a group, revenue uncertainty as measured by the difference in current account surpluses calculated at the low point of oil futures prices (US\$88 per barrel) and the high point (US\$114 per barrel) during the first quarter of 2011 is immense.

The fiscal surplus is estimated to be about 7.5 percent of GDP in 2011, compared with 3 percent in 2010, despite higher discretionary spending measures announced by many of the oil exporters (Algeria, Bahrain, Kuwait, Oman, Saudi Arabia, and Yemen). However, this overall trend masks the actual fiscal stance of many countries, as measured by non-oil fiscal and primary balances. The general government non-oil fiscal balance ton on oil GDP ratio is expected to deteriorate in Iraq, Kuwait, Oman, Saudi Arabia, Sudan, and Yemen.

\section{Despite the Growth, Policy Risks Continue}

Risks are on the downside and could intensify, particularly if the unrest becomes more widespread. The evolving security situation in Libya has already had spillover effects on the region through reduced remittances to Egypt and Tunisia, adding to the challenges facing these countries. Protracted unrest could adversely affect investor sentiment, weigh on private-sector activity (Bahrain, Libya, Oman, and Yemen), and affect the cost and availability of financing for the region as a whole. FDI and the nascent tourism sector will be adversely affected (Bahrain, Libya, Oman, and Yemen), potentially setting back recent progress toward much-needed job creation and economic diversification. Furthermore, equity price declines, if they persist, could dampen recovery in real estate markets and adversely affect financial sector balance sheets (GCC countries). Nevertheless, there are positive spillovers from the GCC countries to the rest of the world.

Short-term fiscal expansions have been financed by higher oil revenues but they may have permanently risen spending. Many MENA oil exporters have ample fiscal space and have increased public spending in response to domestic unrest and increased uncertainty, and to cushion the impact of rising food and fuel prices. In 
Bahrain and Oman, the newly created Gulf Development Fund is expected to provide an additional US\$10 billion to each country (40 percent of 2010 GDP in the case of Bahrain) to finance housing and infrastructure costs, effectively expanding fiscal space. Countries with little fiscal space, such as Iran, Sudan, and Yemen, had initiated measures to enhance non-oil revenues and to contain spending and improve its quality to narrow their fiscal deficits in 2010-2011. Newly announced measures attempt to dampen pressures from higher food prices, provide support to the unemployed, and alleviate housing constrains. The cost of these measures rages between 0.3 percent of GDP (for Algeria) and about 22 percent of GDP (for Saudi Arabia, spread over a number of years). Many of these measures are permanent, and scaling them back may be difficult, which might add to fiscal pressures in the future, particularly if the increase in oil prices in transitory. Iran (substantial subsidy reforms) and Qatar (increase in domestic petrol prices) are exceptions in that they are seeking to reduce distortions that are associated with large subsidies on domestic fuel prices (see Table 3).

Table 3

Recent Fiscal Policy Measures in GCC Countries

\begin{tabular}{|c|c|c|c|c|}
\hline & Description of Measure & $\begin{array}{l}\text { Date } \\
\text { Announced }\end{array}$ & $\begin{array}{l}\text { Estimated Fiscal Cost } \\
\text { (Percent of GDP) }\end{array}$ & $\begin{array}{l}\text { Nature of } \\
\text { Measure }\end{array}$ \\
\hline \multicolumn{5}{|l|}{ GCC } \\
\hline Bahrain & - Provide cash transfers of US\$2,660 each to families & February 13, 2011 & 1.5 & Temporary \\
\hline Kuwait & $\begin{array}{l}\text { - Provide free staple food to citizens for the next } 14 \text { months } \\
\text { together with cash transfers }\end{array}$ & January 17, 2011 & $\begin{array}{c}\text { Above } 2.5 \text { (magnitude } \\
\text { of food subsidy cannot } \\
\text { be quantified at this } \\
\text { time) }\end{array}$ & Temporary \\
\hline Oman & $\begin{array}{l}\text { - Employment for } 50,000 \text { Omanis; establishment of monthly } \\
\text { unemployment benefit of US } \$ 390\end{array}$ & February 27,2011 & 1.25 & Permanent \\
\hline \multirow[t]{5}{*}{ Saudi Arabia } & - Construct 500,000 housing units, build and expand hospitals & March 18, 2011 & \multirow{4}{*}{15} & Temporary \\
\hline & - Pay a two-month salary bonus to state employees & March 18, 2011 & & Temporary \\
\hline & - Increase the public-sector minimum wage by 19 percent & March 18, 2011 & & Permanent \\
\hline & $\begin{array}{l}\text { - Inject capital into specialized credit institutions to facilitate debt } \\
\text { write-offs and increase mortgage lending, provide affordable } \\
\text { housing, and extend social insurance and unemployment benefits }\end{array}$ & February 23,2011 & & Temporary \\
\hline & $\begin{array}{l}\text { - Extend indefinitely the } 15 \text { percent inflation allowance for state } \\
\text { employees that had been phased in over the past } 3 \text { years }\end{array}$ & November 2010 & 1.7 & Permanent \\
\hline \multirow{3}{*}{$\begin{array}{l}\text { United Arab } \\
\text { Emirates }\end{array}$} & - Infrastructure stimulus program focusing on the northern emirates & February 1, 2011 & 0.5 & Temporary \\
\hline & - 70 percent increase in pensions for military personnel & February 1, 2011 & & \multirow[t]{2}{*}{ Permanent } \\
\hline & - State subsidies for rice and bread & February 1, 2011 & & \\
\hline \multicolumn{5}{|c|}{ Other Oil Exporters } \\
\hline Algeria & - Temporary exemption in the tax burden on sugar and edible oil & January 13, 2011 & 0.3 & Temporary \\
\hline \multirow[t]{7}{*}{ Yemen } & - Increase in public wages & January 23, 2011 & 1.4 & \multirow[t]{2}{*}{ Permanent } \\
\hline & $\begin{array}{l}\text { - Expand coverage of the social welfare fund by } 500,000 \text { additional } \\
\text { families }\end{array}$ & January 23, 2011 & 0.2 & \\
\hline & - Pay interim monthly stipend to new school graduates & February 12, 2011 & 0.2 & \multirow[t]{2}{*}{ Temporary } \\
\hline & - Exempt students from paying tuition fees & February 12, 2011 & 0.2 & \\
\hline & - Reintroduce bonuses and allowances to civil servants & February 12, 2011 & 1.0 & Permanent \\
\hline & - Hire 60,000 new graduates & February 12, 2011 & 0.2 & \multirow[t]{2}{*}{ Permanent } \\
\hline & - Other & February 13, 2011 & 0.3 & \\
\hline
\end{tabular}

Note. Source: IMF, 2011a.

Inflation pressures are rising together with concerns about food security. Inflation is expected to increase in almost all countries in 2011, to an average of 11 percent for the oil exporters as a group. The biggest increase is expected in Iran, due to the subsidy reform, but the GCC will also see a pickup in inflation in 2011 to 5.3 percent from 3.2 percent in 2010. The key driver of headline inflation is food prices, but core inflation is increasing in 
many countries, reflecting a rise in inflationary expectations. Key grain prices, including those of corn and wheat, have risen sharply, heightening food security concerns; given that many MENA oil exporters are among the largest importers of wheat in the world Algeria and Iraq, respectively, rank the third and the ninth. World wheat prices rose by over 75 percent in the 12-month period ending on March 31, 2011. Larger harvests resulting from an increase in global acreage and less severe weather conditions should ease some market tightness over the next 12 months. Structural factors (changing diet patterns in emerging and developing economies and the boom in bio-fuels that have buoyed the demand for feedback crops) have also contributed to the rising demand for food. Oil exporters should monitor the second-round effects whereby food inflation translates rapidly into non-food inflation. Some governments, particularly in the GCC (Kuwait, Qatar, Saudi Arabia, and the United Arab Emirates), will need to carefully monitor the impact of expansionary fiscal spending on the aggregate demand to prevent a resurgence of inflationary pressures. So far, only Sudan has tightened monetary policy in response to the emerging inflationary pressures.

\section{Despite Outlook, Reforms Are Needed}

Growth is expected to remain robust, with inflation declining as the food and oil price shocks abate. Importantly, non-oil growth is expected to pick up, which would typically be associated with the increased employment opportunities. Nevertheless, lessons can be drawn from recent developments.

\section{Inclusive Growth}

To be sustainable, growth strategies need to result in job creation and rising incomes for all segments of the population, and address unemployment and housing problems, especially for the youth. In this context, efforts to foster private-sector development should be sustained. Credit plays a vital role in private sector-led growth that would create employment. Ensuring sustainable credit growth with improved access, particularly to small- and medium- sized enterprises, is, therefore, a priority. The success of efforts to diversify the economy will also hinge on the effectiveness of reforms in education stepped-up training for nationals, and the enhanced productivity and the competitiveness will be essential to sustain inclusive growth.

Research is limited on the exact extent and nature of corruption in MENA region. However, there is a general consensus that corruption is widespread in the region and deeply rooted in the political infrastructure of the states (mainly military dictatorships, totalitarian regimes, or monarchies), the institutional of public sector, (typically very large, overstaffed with low salaries) and relatively little opportunities for public participation (U4 Anti-Corruption Resource Centre, 2011).

\section{Better Fiscal Management and Financial Sector Stability}

Public spending has been increased dramatically in recent years in many countries, often allocated towards growth-enhancing physical and social infrastructures. The quality of spending needs greater attention, including the continued strengthening of public financial management. One step would be for additional countries in the region to move away from reliance on untargeted subsidies to more efficient social safety nets. In particular, reforming universal fuel price subsidies would help contain rapidly rising domestic energy consumption. Heightened oil-price volatility has also reinforced the need to cast spending within a multi-year framework to ensure sustainability and improve demand management tools. One option for managing such volatility is to adopt 
a formal fiscal rule, perhaps involving a country-specific aggregate expenditure cast in a three-year rolling budget combined with a debt ceiling. In practice, most GCC countries simply base their budget on a conservative oil price, with no explicit guidance as how or whether additional revenues will be spent. In addition to diminishing the relevance of the budget as a planning document and as an indicator of government priorities, reliance on within-year discretionary adjustments risks generates permanent entitlements that may be difficult to scale back in the event of lower oil prices. It may also magnify boom-bust cycles.

Over the medium term, the MENA oil exporters should continue their efforts to promote the development of the financial system and to improve its efficiency and further increase its resilience. The banking sector remains broadly sound in the GCC countries because banks have high capital buffers, in some cases helped by large government capitalization (Qatar, the United Arab Emirates). Nevertheless, potential vulnerabilities could emerge through spillovers from the nonbank financial sector to the banking sector (Kuwait), the overhang of the real estate sector (Bahrain, the United Arab Emirates), and the interconnectedness between the different segments of the banking system (wholesale and retail banks in Bahrain). Resolution of nonperforming loans of banks in many non-GCC countries (Algeria, Iran), and restructuring of banks (Iraq, Sudan) require continued attention. Finally, debt restructuring in Dubai may imply postponing the realization of losses and a new bout of rollover risks in few years, especially if asset prices fail to recover as anticipated. While law and order are the most relevant determinant of banking sector development, corruption, and investment profile are of secondary importance for banking sector development in MENA countries (Gazdar \& Cherif, 2009). The impact of the global crisis on financial sectors in MENA has been limited so far to GCC countries whose financial sectors were more open to global financial centers but also happened to be in a good position to respond to the financial cushion provided by the past oil surpluses (The World Bank, 2009). Credit to the private sector began to pick up in 2010 in several countries-including the GCC countries, Algeria, and Yemen. Continued efforts will be needed to support the development of the financial system and enhance its regulation and supervision, in order to improve its efficiency and further increase its resilience. Supervisors in all countries should put in place incentives for banks to develop efficient risk management practices. Particularly these are important steps to enhance access to credit for small- and medium- sized enterprises, the promotion of appropriate of domestic debt markets to provide the basis for long-term financing. In the more developed financial systems, existing macro prudential tools should be further refined to manage the credit cycle without fueling inflation, particularly in countries, such as those of the GCC, where monetary policy is constrained by a currency peg.

\section{Conclusions}

Like the other countries, the MENA oil exporters, were adversely affected by the global crisis. They are recently recovering from their recession in 2009 when the global crisis was felt intensively there. Even though growth was accelerated in 2009, mainly driven by the region's oil exporters, the region was on track for recovery from the global crisis until the late 2010, the global economic crisis has a negative impact on the region, especially in the non-exporting oil countries. Average real GDP growth is projected to increase. For the Gulf countries, growth is projected to reach 7.8 percent in 2011 as oil production expands to stabilize global oil supply in the face of supply disruption elsewhere. The oil exporters' combined external current account surplus is 
estimated to increase from US\$172 billion to US\$378 billion and for the Gulf countries from US\$136 billion to US\$304 billion. Inflation pressures are rising together with concerns about food security. Inflation is expected to increase in almost all countries in 2011, to an average of 11 percent for the oil exporters as a group. For most oil exporters, the expected increase in oil prices and production volumes will lead to a higher growth in this year and stronger fiscal and external balances, notwithstanding recent increases in government spending. The quality of spending needs greater attention, including the continued strengthening of public financial management. Heightened oil-price volatility has also reinforced the need to cast spending within a multi-year framework to ensure sustainability and improve demand management tools. To be sustainable, growth strategies need to result in job creation and rising incomes for all segments of the population, and address unemployment and housing problems, especially for the youth. Over the medium term, the MENA oil exporters should continue their efforts to promote the development of the financial system and to improve its efficiency and further increase its resilience. In managing the short-term uncertainties, oil exporters should not lose sight of their longer-term challenges: achieving strong and sustainable inclusive growth to provide employment for the rapidly growing labor force, especially for the youth; better fiscal management; and further development of the financial system.

\section{References}

Drine, I. (2009, June). Impact of the global economic crisis on the Arab region. WIDER Angle Newsletter, $38,2$.

Gazdar, K., \& Cherif, M. (2010, January). Macroeconomic and institutional determinants of stock market development in Mena region: New results from a panel data analysis. International Journal of Banking and Finance, 7(1), 8.

Global Research-MENA. (2011). MENA economic overview. Safat, Kuwait: Global Investment House.

Guetat, I., \& Serranito, F. (2007, February). Income convergence within the Mena countries: A panel unit root approach. The Quarterly Review of Economics and Finance, 5(46), 685-706.

International Monetary Fund (IMF). (2011a, April). Regional economic outlook: Middle East and central Asia. Washington, D. C.: IMF Publication.

International Monetary Fund (IMF). (2011b). Economic transformation in MENA: Delivering on the promise of shared prosperity. Deauville, France: IMF Publication.

Makdisi, S., Fattah, Z., \& Limam, I. (2000, June). Determinants of the growth in the MENA countries. The Global Development Network-Economic Research Forum (ERF), Prague, Working Paper, Serial No: API/WPS 0301. Kuwait: Arab Planning Institute.

Moriyama, K. (2010). The spillover effects of the global crisis on economic activity in MENA emerging market countries-An analysis using the financial stress index. IMF Working Paper, WP/10/8.Washinghton, D. C: IMF Publication.

Nabli, M. K. (2010). The great recession and developing countries: Economic impact and growth prospects. Washington, D. C.: The World Bank Publication.

The World Bank. (2005). Why some MENA countries did better than others? The road not travelled: Education reform in the Middle East and North Africa. Washington, D. C: The World Bank Publication.

The World Bank. (2009). Navigating through the global recession, Middle East and North Africa region. 2009 Economic Developments and Prospects. Washington, D. C.: The World Bank Publication.

U4 Anti-Corruption Resource Centre. (2011). Overview of corruption in MENA countries. Washington, D. C.: U4 ACRC. Wikipedia. (2011). MENA. Retrieved September 23, 2011, from http://www.en.wikipedia.org/wiki/MENA 